\title{
DOI https://doi.org/10.30525/978-9934-26-181-7-11
}

\section{ВІЙСЬКОВІ ФОРМУВАННЯ ПЕШМЕРГА В ІРАКСЬКОМУ КУРДИСТАНІ (ДРУГА ПОЛОВИНА ХХ - ПОЧАТОК ХХІ СТ.)}

\author{
Ямпольська Л. М. \\ кандидат історичних наук, доцент, \\ доиент кафедри всесвітньої історії \\ Харківський національний педагогічний університет \\ імені Г. С. Сковороди \\ м. Харків, Україна
}

Курдські військові традиції існували з давніх часів і розвивалися разом із прагненням курдського народу до власної державності. Ранній курдизм і курдські військові формування в різні історичні періоди боролися проти Сефевідської, Османської, Британської імперій. Незважаючи на жорстоке переслідування османським урядом, курдські племінні ополчення в період Першої світової війни співпрацювали зі збройними силами Османської імперії, допомагаючи у здійсненні геноциду асирійців, вірмен і греків [3, с. 169].

Завдання нашої доповіді - проаналізувати історію створення, склад, визначити основні вектори діяльності збройних формувань пешмерга у курдсько-іракському конфлікті другої половини XX - початку XXI ст. Ці аспекти практично не отримали висвітлення в сучасному українському курдознавстві [2; 4-5].

Пешмерга (курд. Pêşmerge: pêş - «перед», merg - «смерть», е - «€»: «ті, що дивляться в обличчя смерті») - курдські воєнізовані формування в Іракському Курдистані. Виникли з появою курдського національного pyху у 90-х pp. ХІХ ст. За часів самопроголошеної Мехабадської Республіки (1946-1947) на чолі з Мустафою Барзані стали ії офіційною армією [8]. Назва пешмерга остаточно оформилася в середині XX ст. як курдський еквівалент ірансько-арабському поняттю «федаї», яким іменували воїнів, що присвятили себе боротьбі за високу ідею. Термін «пешмерга» вперше у ЗМІ використав курдський письменник, поет i політичний діяч Ібрагім Ахмед [5, с. 172].

Під час Вересневого повстання іракських курдів проти національної політики офіційного Багдада у 1961-1975 pp. (курдсько-іракський конфлікт) загони пешмерга, чисельністю близько 15 тис. осіб, перетворилися на регулярні військові формування. Їх переважна більшість була підпорядкована лідерові Демократичної партії Курдистану (Democratic 
Party of Kurdistan - DPK) Мустафі Барзані [1, с. 56]. Збройне повстання курдів, придушене Багдадом, дискредитувало ідею автономії (11 березня 1974 р. рішенням Ради революційного командування (РРК) був прийнятий Закон № 33 «Про автономію Курдистану», що оголошував про створення Курдського автономного району (КАР) із центром у м. Ербілі), у середовищі курдів поширювалася зневіра у можливість здобуття національних прав мирними політичними засобами [4, с. 156].

Після поразки Вересневого повстання у лавах DPK відбувся розкол: Джаляль Талабані вийшов із партії і з метою активізації опору офіційному Багдаду заснував Патріотичний союз Курдистану (Patriotic Union of Kurdistan - PUK). Фракційність і партикуляризм поглибили протистояння між провідними політичними силами курдського національного руху, яке до сьогоднішнього часу розділяє сили пешмерга й суспільство Республіки Ірак. Після смерті Мустафи Барзані в 1979 р. лідером DPK став його син Масуд. У міру зростання напруженості у відносинах між DPK і PUK у 1980-х - 1990-х рр. більшість пешмерга боролися за збереження курдських регіонів (Дохук, Ербіль, Сулейманія, Халабджа, Кіркук, Ніневія, Діяла) під контролем своєї партії, одночасно борючись із вторгненням іракської урядової армії.

Після Першої війни у Перській затоці 1991 р. в Іракському Курдистані активізувалося протистояння між DPK і PUK, і сили пешмерга активно використовувалися під час збройних зіткнень [6]. Громадянська війна офіційно закінчилася у вересні 1998 р., коли курдські лідери М. Барзані й Д. Талабані підписали Вашингтонську угоду про встановлення миру, розподіл влади і прибутків, заборону дислокації на території Північного Іраку Робітничої партії Курдистану, недопущення іракських урядових військ до курдських регіонів [7]. У наступні роки напруженість залишалася високою, проте обидві політичні сили рухались назустріч одна одній, і під час Другої війни у Перській затоці 2003 р. разом із підпорядкованими їм пешмерга взяли участь у поваленні режиму Саддама Хусейна.

Аналізуючи кількісний і якісний склад пешмерга, слід зазначити, що DPK i PUK не розголошують статистичну інформацію про винищувачів пешмерга в офіційних документах. ЗМІ припускають, що бійців налічується від 150 до 200 тис. [9]. Пешмерга розділили Іракський Курдистан на «жовту» зону, що регулюється DPK (губернаторства Дохук і Ербіль) i «зелену» зону, керовану PUK (губернаторства Сулейманія і Халабджа) [9]. Кожна зона має власну філію пешмерга зі своїми владними установами. Через фракційність і партикулярний характер політичних сил пешмерга не мають єдиного командного центру, а їхні підрозділи дотримуються 
окремої військової ієрархії в залежності від лояльності до певної політичної сили.

На сьогодні пешмерга - це збройні сили Kurdistan Autonomous Region - Курдського автономного району (КАР) Республіки Ірак. Операції Антиіракської коаліції в 1991 та 2003 рр. і подальші політичні зміни привели до ратифікації нової конституції Іраку у 2005 р., відповідно до якої КАР має статус широкої автономії. Іракський Курдистан поділений на чотири провінції - Дохук, Ербіль, Сулейманію і Халабджу. Між іракським урядом і курдським регіоном триває протистояння щодо курдофонних територій - провінцій Кіркук, Ніневія і Діяла, які офіційно не входять до складу Іракського Курдистану.

Ще одним потужним вектором діяльності пешмерга стала участь у боротьбі з радикальною терористичною організацією - Ісламською Державою Іраку і Леванту (ІДІЛ). Після захоплення бойовиками ІДІЛ у червні 2014 р. курдофонних провінцій Кіркук і Ніневії та широкомасштабного винищення єзидів пешмерга активізували військові дії проти ІДІЛ, що сприяло перемозі над нею сил коаліції. Пешмерга відвоювали Кіркук, який фактично перейшов під контроль Іракського Курдистану. Проте у середині жовтня 2017 р. за результатами Іраксько-курдської війни офіційний Багдад знову повернув контроль над провінцією [5, с. 173].

Оскільки іракській армії законодавством заборонено перетинати кордони КАР, за його безпеку відповідають пешмерга, а також їхні дочірні організації, до яких належать Asayish (розвідувальне агентство), Parastin u Zanyari (допоміжне розвідувальне агентство) та Zeravani (жандармерія). Формально пешмерга знаходяться під командуванням Kurdistan Regional Government's Ministry of Peshmerga Affairs (Міністерства у справах пешмерга Регіонального уряду Курдистану) [9]. У період боротьби з ІДІЛ сили Західної коаліції здійснювали тиск на PUK та DPК, щоб створити змішані бригади пешмерга як умову подальшої допомоги та фінансування. Незважаючи на об'єднання 12 бригад під регіональним керівництвом, офіцери продовжують звітувати і отримувати накази від свого партійного керівництва, яке контролює розміщення лояльних до нього збройних сил і призначає командирів фронту та окремих секторів.

У складі сил пешмерга наявні наступні підрозділи: Regional Guard Brigades - Регіональні гвардійські бригади (40-43 тис., підпорядковані Міністерству у справах Пешмерга, аполітичні), Hezekani Kosrat Rasul (2-3 тис., польовий командир Косрат Расул Алі, PUK), Anti-terror Force Антитерористичні сили (5 тис., командувач Лахур Шейх Джангі, PUK), Presidential Peshmerga Brigades - Президентські бригади пешмерга (командувач Херо Ібрагім Ахмед, PUK), 70 об'єднань PUK 
(60 тис., командувачі Шейх Джафар, Шейх Мустафа), Emergency Forces Сили спеціального призначення (3 тис., PUK), Nechirvan Barzani's Brigade - бригада Нечирвана Барзані (DPK), 80 об'єднань DPK (70-90 тис., командувач Наджат Алі Саліх), Zerevani (51-120 тис., командувач Масуд Барзані, DPK), Ezidhan Protection Force - Сили для захисту єзидів (7-8 тис., командувач Масуд Барзані, DPK) [6]. Сучасні пешмерга не мають належного медичного забезпечення та підрозділів зв'язку. Під керівництвом коаліції, очолюваної США, пешмерга почали стандартизувати свою систему озброєнь, замінивши зброю радянських часів на вогнепальну зброю НАТО [9].

Негативним проявом політичної діяльності пешмерга $\epsilon$ їх використання DPK і PUK для здійснення монополії на застосування сили в своїх зонах. У 2011 р. пешмерга, контрольовані DPK, обстріляли антиурядових протестувальників у Сулейманії, а пізніше PUK використав власні сили безпеки, щоб зірвати ці протести, що призвело до критики 3 боку опозиційних партій у парламенті. У 2014 р. DPК використала свої пешмерга, щоб зупинити депутатів руху «Горран», які хотіли взяти участь у роботі Регіонального парламенту в Ербілі [6]. За межами Іракського Курдистану пешмерга обвинувачуються у використанні сили для здійснення контролю над арабськими, єзидськими та асирійськими громадами.

Таким чином, становлення пешмерга проходило у другій половині XX - на початку XXI ст. у боротьбі Іракського Курдистану за автономію (курдсько-іракський конфлікт) та «з ворогами Курдистану». Незважаючи на ідейно-патріотичну спрямованість, на військово-політичну діяльність пешмерга впливали партикуляризм, клановість, комерціалізація війн «четвертого покоління», етноконфесійні конфлікти, зовнішній фактор, унеможливлюючи реалізацію основного завдання курдизму - власного державотворення.

\section{Література:}

1. Барзани М. Мустафа Барзани и курдское освободительное движение (1931-1961 гг.): пер. с курдск. А.Ш. Хаурами. СПб.: Наука, $2005.370 \mathrm{c}$.

2. Наджат С. Відносини між Іракським Курдистаном та Іраком у другому десятилітті XXI століття: пошук оптимальної моделі співіснування. Політичне життя. 2018. № 4. С. 102-106.

3. Степанова Н.В. Проблема курдов в Ираке. Этносы и конфессии на Востоке: конфликты и взаимодействие. Под ред. А.В. Торкунова; 
сост. В.Я. Белокреницкий, М.А. Сапронова. М.: МГИМО МИД РФ, 2005. С. $168-220$.

4. Ямпольська Л.М. Курдський національний рух і військовополітична діяльність Мустафи Барзані (1903-1979). Гілея: науковий вісник. 3б. наук. праџь. К.: «Видавництво «Гілея», 2017. Вип. 122 (7). C. $153-158$.

5. Ямпольська Л.М. Курдський національний рух і «проблема Кіркуку» в контексті державотворчих процесів Іраку новітнього періоду. Гілея: науковий вісник. К.: «Видавництво «Гілея», 2019. Вип. 147 (№ 8), Ч. 1. Історичні науки. С. 170-177.

6. Lortz G. Michael. Willing to face Death: A History of Kurdish Military Forces - the Peshmerga - from the Ottoman Empire to Present-Day. URL: https://web.archive.org/web/20131029191132/http://etd.lib.fsu.edu/ theses/available/etd-11142005-144616/unrestricted/003Manuscript.pdf

7. Mohammad V.A. Ahmed. Iraqi Kurds and Nation-Building. URL: http://csis.org/files/publication/140105_Iraq_Book_AHC.pdf

8. Mufid Abdulla. Mahabad - the first independent Kurdish republic. The Kurdistan Tribune. February 14, 2015.

9. Wilgenburg van W., Fumerton M. Kurdistan's Political Armies: The Challenge of Unifying the Peshmerga Forces. URL: https:// carnegieendowment.org/files/ACMR_WilgenburgFumerton_Kurdistan_Englis h_final.pdf 